\title{
KEWIRAUSAHAAN NAMEKO (NASI MERAH KOTAK-KOTAK) DALAM MENGGIATKAN PANGAN LOKAL YANG SEHAT
}

\author{
Hengki Wijaya ${ }^{1)}$, Tuflikha Primi Putri ${ }^{2)}$ \\ 1) Mahasiswa Pascasarajana Prodi Ilmu Pendidikan Universitas Negeri Makassar, Sulawesi Selatan \\ Dosen Sekolah Tinggi Filsafat Jaffray Makassar, Sulawesi Selatan \\ hengkilily1988@gmail.com \\ 2) Prodi Ilmu dan Teknologi Pangan Universitas Hasanuddin, Makassar, Sulawesi Selatan
}

\begin{abstract}
ABSTRAK
Tulisan ini adalah gabungan multidisiplin ilmu yaitu ilmu pangan, ilmu pendidikan kewirausahaan. Suatu usaha menggiatkan nasi merah yang sehat dalam usaha kewirausahaan dengan nama dagang Nasi merah kotak-kotak (Nameko) yang sehat, bergizi dan tanpa penyedap rasa buatan pabrik. Dalam mata kuliah entrepreneurship mahasiswa mengembangkan formulasi yang tepat yang mengikuti langkah-langkah prosedur pembuatan nameko, biaya pembuatan, dan uji organoleptik hingga menentukan desain kotak sebagai pengemas produk. Melalui penelitian eksperimen di kelas tersebut didapatkan produk nameko yang sehat, dan memanfaatkan produk pangan yang rendah glukosa yang dapat menyebabkan diabetes. Nameko memiliki nilai ekonomis yang dapat menjadi makanan alternatif yang sehat bagi kesehatan.
\end{abstract}

\section{Kata Kunci: nasi merah; pangan lokal; nameko; kewirausahaan, uji organoleptik}

\section{PENDAHULUAN}

Pemanfaatan beras sebagai bahan makanan pokok sudah menjadi tren bagi masyarakat Indonesia pada umumnya. Kebiasaan masyarakat Indonesia akan beras putih terus meningkat, sementara selain ada beras putih adapula beras merah, dan lainnya. Produksi beras secara keseluruhan pada tahun 2016 untuk Sulawesi Selatan mencapai 5.727.081 ton dan meningkat secara kuantitas di tahun 2017 yaitu 6.055.404 ton. Namun menurun secara produktivitas $(\mathrm{Ku} / \mathrm{Ha})$ dari 51,96 pada tahun 2016 menjadi 50,93 pada tahun 2017. Hal ini berarti luas lahan semakin bertambah namun produksi beras tidak meningkat secara signifikan (2017).

Beras putih (Oryza sativa) yang diolah menjadi nasi putih masih menjadi tren saat ini dibandingkan dengan nasi merah dari beras merah (Oryza nirvana). Beras menjadi kebutuhan dunia sebagai pangan lokal yang dikonsumsi oleh penduduk dunia sebagai kalori utama termasuk penduduk Indonesia. Bila membandingkan beras putih dengan beras merah dari aspek gizi dan manfaatnya bagi kesehatan maka beras merah lebih unggul.

Dari segi kesehatan beras merah mengandung gen yang memproduksi antosianin, antosianin yang dihasilkan merupakan sumber warna merah yang terdapat pada kondisi fisik beras. Senyawa yang terdapat pada lapisan warna merah beras bermanfaat sebagai antioksidan, anti kanker, anti glikemik tinggi. Kulit ari beras merah ini kaya akan minyak alami, lemak essensial, dan serat (Adriani, 2018;Santika, 2010). Namun masyarakat mulai sadar akan pentingnya kesehatan, sehingga masyarakat mulai mengkonsumsi makanan yang bermanfaat untuk kesehatan seperti makanan berserat. Contoh bahan pangan yang mengandung serat adalah beras merah dan bekatul (Marcellina, 2012).

Segi gizi beras merah tumbuk mengandung 216,45 kalori, 88\% kecukupan harian (daily value - DV) mineral pangan, 27\% DV selenium, 21\% DV magnesium, 18,8\% DV asam amino triftofan, 3,5 gram serat (beras putih mengandung kurang dari 1 gram), dan proteinnya 2,5\% lebih tinggi dari beras putih. Selain itu juga mengandung asam lemak alfa-linolenat, zat besi, vitamin B kompleks, dan vitamin A (Adriani, 2018; Muchtadi, 1992). Sumber mineral dalam beras merah lebih tinggi dari beras putih (Govarethinam, 2014). Di Indonesia padi yang berasnya berwarna merah (padi beras merah) kurang mendapat perhatian dibandingkan dengan padi yang berasnya berwarna putih (padi beras putih) padahal beras merah mengandung gizi tinggi

\footnotetext{
${ }^{1}$ Korespondensi penulis: Hengki Wijaya, Telp 085298038071, hengkilily1988@gmail.com
} 
(Widiyanti dan Cahyadin, 2015). Nasi merah mengandung kadar serat yang tinggi dibandingkan dengan nasi putih. Nasi merah mengandung vitamin dan mineral tingkat tinggi, khususnya vitamin B1, dan magnesium. Serat makanan beras merah dapat menjelaskan peningkatan fungsi endotel (Kondo et al. 2017). Dengan demikian asupat serat tinggi pada beras merah dan kandungan vitamin, serta mineralnya dapat menjadi asupan gizi bagi tubuh manusia.

Beras merah adalah pangan lokal yang harus digiatkan karena memiliki gizi, dan manfaat bagi kesehatan tubuh. Nasi merah bermanfaat bagi penderita diabetes, dan juga untuk mencegah meningkatnya kadar gula darah glukosa yang dapat menyebabkan diabetes. Rensiansi, dan Iwaningsih (2016) mengungkapkan bahwa "Penyandang diabetes masih dapat mengonsumsi beberapa jenis nasi yang memiliki kisaran Indeks Glikemik (IG) rendah hingga sedang, seperti nasi dari beras varietas IR-36 dan nasi merah." Beras merah termasuk kategori makanan dengan indeks glikemik sedang. Semakin rendah IG makanan, semakin rendah pula kemampuannya meningkatkan kadar glukosa darah (Dn et al. 2018). Hasil penelitian Kondo et al. (2017) menyimpulkan bahwa intervensi dengan diet kaya serat dengan beras merah secara efektif meningkatkan fungsi endotel, tanpa perubahan kadar $\mathrm{HbAlc}$ melalui pengurangan kandungan glukosa. Beras berkontribusi untuk energi utama diet untuk tubuh. Beras merah pra-kecambah memiliki protein dua kali lebih banyak daripada nasi putih, yaitu 14,6 g/100 g (beras merah) dibandingkan 7,3 g/100 g (nasi putih). Sebaliknya, kandungan lemaknya sangat tinggi, yaitu 24,8 g/100 g untuk beras merah prakecambah dan 1,5 g/100 g untuk nasi putih (Helmiyati, Hapsari, dan Setyaningrum, 2014). Selain itu, beras merah dikenal untuk meningkatkan intoleransi glukosa dan mencegah timbulnya diabetes (Vora, Madhrani, and Sarman, 2015). Resistensi insulin dan kolesterol total serta kadar kolesterol LDL berkurang setelah konsumsi nasi merah. Konsumsi nasi merah bermanfaat karena penurunan sebagian respons glikemik, dan dapat melindungi fungsi endotel postprandial pada subjek dengan sindrom metabolik (Shimabukuro et al., 2014). Hal ini berarti bahwa beras merah memiliki kemampuan untuk mencegah peningkatan kandungan glukosa dalam darah glikemik, dan menurunkan karena memiliki serat yang tinggi.

Namun yang menjadi permasalahan lain adalah minat masyarakat yang masih rendah untuk menikmati olahan beras merah dalam bentuk nasi merah. Lebih banyak penggunaan nasi putih, dan kebiasaan penduduk Indonesia untuk mengomsumsi nasih putih dibandingkan nasi merah meskipun mereka telah mengetahui manfaatnya bagi kesehatan. Oleh karena itu, untuk mewujudkan ide nasi merah menjadi prioritas dalam makanan kuliner yang diminati maka penulis bekerja sama dengan mahasiswa Sekolah Tinggi Filsafat Jaffray Makassar yang mengikuti kuliah entrepreneurship (kewirausahaan) membuat tugas proyek dalam membuat makanan yang bergizi dengan kandungan serat yang tinggi berbahan nasi merah dengan lauk pauk yang ditentukan. Tujuan penelitian ini adalah menggiatkan pangan lokal beras merah untuk membuat produk nasi merah kotak-kotak (Nameko) yang sehat, dan memiliki nilai jual ekonomis sebagai suatu kewirausahaan mahasiswa di kampus. Urgensi penelitian ini adalah memanfaatkan pangan lokal beras merah yang belum optimal digiatkan menjadi bahan pangan prioritas dengan menjadikan nasi merah sebagai pengganti nasi putih dalam industri kuliner di Indonesia khususnya Sulawesi Selatan.

Beberapa penelitian yang serupa dengan pemanfaatan beras merah yaitu: beras merah dijadikan tepung beras merah yang disubtitusikan dalam tepung terigu dalam pembuatan mi (Adriani, 2018). Penelitian pembuatan roti tawar berbasis beras merah dan bekatul (Marcellina, 2012). Namun dalam riset ini penulis akan memanfaatkan beras merah (Oryza nirvana) menjadi nasi merah yang diolah dan menjadikan nasi merah sebagai pangan lokal yang sehat dalam industri kuliner saat ini.

\section{METODE PENELITIAN}

Bahan-bahan yang digunakan adalah beras merah yang akan diolah menjadi nasi merah. Bahan pangan yang lain seperti tempe, kacang merah, jagung, sayur, ayam kampung, kelapa, dan bumbu-bumbu lainnya tanpa penyedap rasa. Dalam riset ini melibatkanpanelis sekaligus mahasiswa yang terlibat dalam proyek pembuatan Nameko yang terbagi atas dua kelompok. Responden adalah mahasiswa yang mengambil mata kuliah entrepreneurship. 
Prosedur penelitiannya adalah pembuatan nasi merah kotak-kotak (Nameko) dengan lauk pauk yang dibuat oleh kelompok yang sebelumnya telah dipresentasikan melalui tulisan proposal kewirausahaan termasuk di dalamnya menjelaskan mengapa memilih nama produk Nameko dan lauk pauknya. Selanjutnya produk Nameko diuji secara organoleptik yaitu uji Pemilihan/Penerimaan (preference test/acceptance test). Selanjutnya hasil uji organoleptik didiskusikan dalam Focus Group Discussion (Kinalski et al. 2017) bersama dosen kewirausahaan yang memiliki kepakaran teknologi pangan.

Adapun uji Pemilihan/Penerimaan (preference test/acceptance test) menyangkut penilaian seseorang akan suatu sifat atau kualitas suatu bahan yang menyebabkan orang menyenangi. Pada uji ini panelis mengemukakan tanggapan pribadi yaitu kesan yang berhubungan dengan kesukaan atau tanggapan senang atau tidaknya terhadap sifat sensoris atau kualitas yang dinilai (Anonim, 2006). Tujuan uji penerimaan ini untuk mengetahui apakah suatu komoditi atau sifat sensorik tertentu dapat diterima oleh masyarakat. Uji ini tidak dapat untuk meramalkan penerimaan dalam pemasaran. Hasil uji yang menyakinkan tidak menjamin komoditi tersebut dengan sendirinya mudah dipasarkan (Anonim, 2006).

Uji Penerimaan meliputi uji kesukaan atau uji hedonik dan uji mutu hedonik (Aberoumand, 2015). Pada uji hedonik panelis mengemukakan tanggapan pribadi suka atau tidak suka, disamping itu juga mengemukakan tingkat kesukaannya. Tingkat kesukaan disebut juga skala hedonik. Skala hedonik ditransformasi ke dalam skala numerik dengan angka menaik menurut tingkat kesukaan. Sedangkan pada uji mutu hedonik panelis menyatakan kesan pribadi tentang baik atau buruk (kesan mutu hedonik). Kesan mutu hedonik lebih spesifik dari kesan suka atau tidak suka, dan dapat bersifat lebih umum (Anonim, 2006). Selanjutnya setelah melakukan uji organoleptik maka panelis bergabung dalam Focus Group Dicussion (FGD) sebagai evaluasi terhadap kedua produk Nameko. Sedangkan untuk desain kotak produk Nameko bekerja sama rekan desain kotak berpengalaman. Selanjutnya dihasilkan produk akhir.

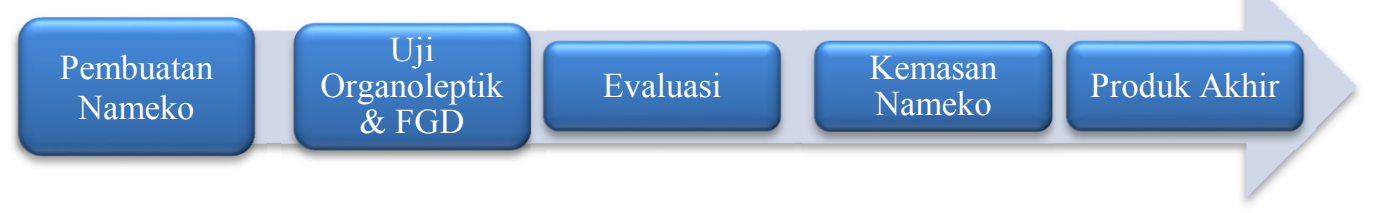

Gambar 1. Prosedur Pembuatan Nameko hingga Produk Akhir

\section{HASIL DAN PEMBAHASAN}

\section{Uji Organoleptik}

Metode yang dipakai untuk uji organoleptik dalam penelitian ini adalah uji hedonik. Panelis diminta untuk memberikan kesan suka atau tidak suka terhadap suatu karakteristik mutu yangdisajikan dan kemudian dilanjutkan dengan tingkat kesukaannya. Tingkat kesukaan skala hedonik berkisar antara amat sangat suka sampai amat sangat tidak suka. Pada bagian ini nasi merah yang diolah oleh dua kelompok untuk diuji tekstur, dan rasa nasi merah dengan perlakuan yang berbeda yaitu nasi merah dengan perlakuan dimasak dengan air tertentu, dan perlakuan dengan penambahan agar-agar dan air tertentu. Duabelas panelis memberikan penilaian uji hedonik yang dijabarkan pada tabel 1 dan 2 .

Tabel 1. Penilaian Tekstur Nasi Merah

\begin{tabular}{|c|l|c|c|}
\hline No & \multicolumn{1}{|c|}{ Parameter } & Nameko Original & Nameko Fit \\
\hline 1 & Keras & - & 1 \\
\hline 2 & Agak Keras & 10 & 10 \\
\hline 3 & Agak lunak & 2 & 1 \\
\hline 4 & Lunak & - & - \\
\hline
\end{tabular}

Penilaian tekstur nasi merah dalam produk nameko original menujukkan bahwa panelis yang memilih kesukaannya bahwa nasi merah yang agak keras adalah 10 panelis $(83,33 \%)$, dan $2(16,67 \%)$ yang memilih bahwa nasi merah lunak. Sementara untuk nasi merah Nameko Fit, penelis juga memilih kesukaannya bahwa nasi merah yan digunakan dalam Nameko fit adalah agak keras $(83,33 \%)$, dan 1 panelis lebih menyukai nameko fit karena teksturnya keras $(8,33)$. Adapun panelis menilai bahwa nasi merah agak lunak $(8,33 \%)$. Tekstur agak keras dipilih panelis karena tekstur nasi merah agak keras, dan terhambur. 
Sekalipun berbeda dengan tekstur nasi putih yang agak lunak, namu tekstur agak keras adalah menjadi ciri khas nasi merah.

Tabel 2. Penilaian Rasa Nasi Merah

\begin{tabular}{|c|l|c|c|}
\hline No & \multicolumn{1}{|c|}{ Parameter } & Nameko Original & Nameko Fit \\
\hline 1 & $\begin{array}{l}\text { Rasanya sama dengan } \\
\text { nasi puth }\end{array}$ & - & - \\
\hline 2 & Rasa hambar & 12 & 11 \\
\hline 3 & Rasa manis & - & - \\
\hline 4 & Rasa agak manis & - & 1 \\
\hline
\end{tabular}

Penilaian rasa nasi merah terhadap rasa menunjukkan panelis memilih bahwa nasi merah pada nameko original adalah $100 \%$ rasa hambar. Sementara pada nameko fit terdapat $91,67 \%$ menyatakan hambar dan yang menyatakan rasa agak manis 1 panelis $(8,33 \%)$. Rasa nasi putih adalah manis berbeda dengan nasi merah yang cenderung hambar. Rasa hambar pada nasi merah menunjukkan bahwa lebih rendah glukosa daripada nasi putih. Beras merah ini tidak dicampurkan dengan beras putih karena produk kuliner ini menggunakan $100 \%$ beras merah.

Penilaian produk nameko original dan nameko fit dilaksanakan melalui diskusi dengan metode FGD (Focus Group Discussion). Pada bagian ini dibahas penilaian panelis secara keseluruhan terhadap kedua produk nameko. Pada gambar 2 di bawah tersedia menu Nameko original tanpa penyedap rasa (MSG) yaitu nasi merah, ayam goreng tepung, tempe bacem, dan sayur jagung. Penilaian panelis didasarkan pada keseluruhan lauk pauk dan nasi merah. Rasa tempe bacem, sayur jagung, dan ayam tepung dapat membantu panelis untuk menghabiskan nasi merah yang terkesan sulit dihabiskan, disamping butiran-butiran nasi merah yang kasar saat panelis mengunyahnya. Penggunaan bumbu alami tanpa MSG tidak mengurasi rasa lauk pauk untuk digabungkan dengan nasi merah. Kuah sayur jagung dapat membantu panelis untuk mengunyah nasi merah saat dalam mulut panelis. Evaluasi nameko original terletak ayam tepung yang tidak terlalu garing.

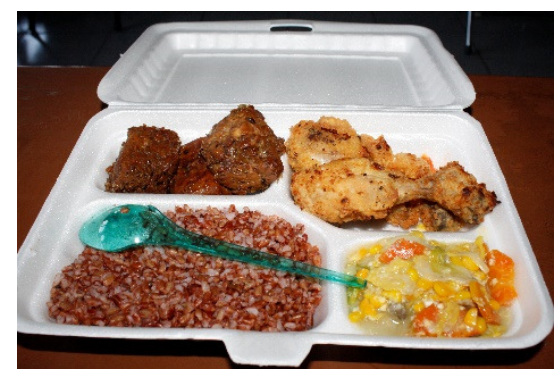

Gambar 2. Nameko Original

Produk nameko fit pada gambar 3 di bawah memiliki target konsumen yang ditujukan kepada masyarakat yang suka berolahraga dan menyukai makanan yang sehat. Nasi merah, sayur jagung, kacang merah, dan sup dada ayam dengan rempah memberikan rasa yang tidak biasa. Panelis memahami bahwa nameko fit ini seperti kuliner yang benar-benar ditujukan pada masyarakat yang ingin makanan sehat, dan juga penderita diabetes. Evaluasi pada menu ini adalah kematangan pada kacang merah yang perlu dilakukan perendaman sebelumnya supaya teksturnya lunak. Nasi merahnya yang padat dan ada penambahan agar-agar untuk memadatkan menambah rasa nasi merah yang sedikit berbeda dengan nasi merah nameko original. 


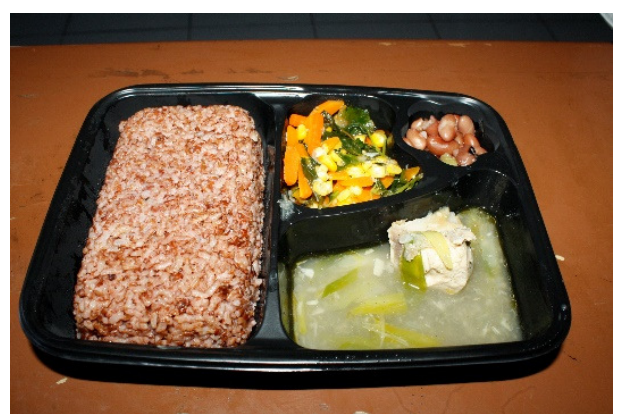

Gambar 3. Nemeko Fit

Biaya pembuatan nameko original lebih murah daripada nameko fit karena bahan-bahannya dan bumbunya. Dalam pembuatan dalam jumlah banyak termasuk misalnya 10 dos maka biaya per dos yaitu $\mathrm{Rp}$ 12.800,-. Biaya pembuatan nameko fit sekitar Rp 13.600,-. Produk nameko ini dapat dijual pada kisaran $\mathrm{Rp}$ 15.000-20.000,-. Biaya kemasan dos (Rp 700,-/eksamplar) untuk pembuatan cetakan dua ribu dos. Desain disesuaikan dengan konsep nasi merah kotak-kotak dengan slogan "Ingat Nasi Kotak Ingat Nameko" karya Rizky Prakarsa Satria (alumni STF Jaffray Makassar tahun 2018).

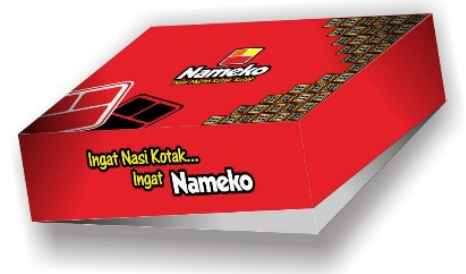

\section{Gambar 4. Desain Kotak Nameko (Nasi Merah Kotak-kotak)}

Kewirausahaan mahasiswa yang dilakukan dalam proyek tugas kewirausahaan dengan ide makanan sehat dari pangan lokal yang menggiatkan beras merah yang dijadikan beras merah untuk bahan utama makanan sehat bergizi dapat membantu masyarakat untuk memilih alternatif kuliner di masyarakat. Pemasaran nameko saat ini dapat dilakukan melalui aplikasi Go Food dan sejenisnya sehingga tidak membutuhkan warung atau sejenisnya. Produk ini pun dapat disebarluaskan kepada masyarakat yang ingin menggiatkan pangan lokal nasi merah dengan menu yang berbeda misalnya dengan menjadikan nasi merah goreng dengan penyedap rasa alami dari bumbu nusantara.

\section{KESIMPULAN}

Kesimpulan yang didapatkan melalui proyek kuliner nameko ini adalah:

1) Produk nameko dengan bahan utama nasi merah dan lauk pauk tertentu dapat diterima dengan baik melalui uji organoleptik.

2) Nilai gizi nasi merah secara klinis lebih baik daripada nasi putih dan berdampak terhadap kesehatan dan cocok bagi penderita diabetes.

3) Biaya produksi dan harga jual terjangkau dan pemasaran yang semakin mudah melalui aplikasi penjualan makanan.

4) Kewirausaan nameko dapat dilakukan oleh siapa saja, dan dapat mengembangkan bahan pangan lokal nasi merah ini menjadi fokus bahan pangan sehat bagi kebutuhan jasmani masyarakat.

5) Melalui proyek ini sesama petani dapat mendorong untuk menanam padi jenis beras merah di lahan mereka.

\section{DAFTAR PUSTAKA}

Aberoumand, Ali. 2015. "Production and Evaluation of Organoleptic Characteristics of Fruit Juice and LowSugar Pulp of Behbahan Variety Dates of Kasi and Kabkab." African Journal of Food Science 9(5):322-25. 
Adriani, Risa. 2018. "Pengaruh Perbandingan Tepung Terigu (Triticum Aestivum) Dan Tepung Beras Merah (Oryza Nirvana) Terhadap Karakteristik Mie Kering.” Universitas Pasundan, Bandung.

Anon. 2006. "Pengujian Organoleptik (Evaluasi Sensori) Dalam Industri Pangan." Retrieved (http://tekpan.unimus.ac.id/wp-content/uploads/2013/07/Pengujian-Organoleptik-dalam-IndustriPangan.pdf).

BDSP. 2017. "Pusat Data Dan Sistem Informasi Kementerian Pertanian." Kementerian Pertanian Republik Indonesia. Retrieved January 12, 2019 (https://aplikasi2.pertanian.go.id/bdsp/id/indikator).

Dn, Herlina, Nesha Trt, Noor F, Okki A, Ebigail D, and Darmawati Ai. 2018. "Pengaruh Pemberian Beras Merah Terhadap Kadar Gula Darah Tikus Wistar." Media Medika Muda 2(2).

Govarethinam, Bagirathy A. 2014. "A Comparative Study Of Mineral Contents In Selected Malaysian Brown Rice And White Rice." University of Malay, Kuala Lumpur.

Helmiyati, Siti, Mirza Hapsari, and Dwi Larasati Setyaningrum. 2014. "Rice in Health and Nutrition." International Food Research Journal 21(1):13-24.

Kinalski, Daniela Dal Forno, Cristiane Cardoso de Paula, Stela Maris de Mello Padoin, Eliane Tatsch Neves, Raquel Einloft Kleinubing, and Laura Ferreira Cortes. 2017. "Focus Group on Qualitative Research: Experience Report.” Revista Brasileira de Enfermagem 70(2):424-29.

Kondo, Keiko, Katsutaro Morino, Yoshihiko Nishio, Atsushi Ishikado, Hisatomi Arima, Keiko Nakao, Fumiyuki Nakagawa, Fumio Nikami, Osamu Sekine, Ken-ichi Nemoto, Makoto Suwa, Motonobu Matsumoto, Katsuyuki Miura, Taketoshi Makino, Satoshi Ugi, and Hiroshi Maegawa. 2017. "FiberRich Diet with Brown Rice Improves Endothelial Function in Type 2 Diabetes Mellitus: A Randomized Controlled Trial” edited by G. D. Norata. PLOS ONE 12(6):e0179869.

Marcellina, Elvira. 2012. "Aplikasi Metode Quality Function Deployment (QFD) Dalam Studi Pengembangan Produk Roti Tawar Berbasis Beras Merah Dan Bekatul.” Prodi Teknologi Pertanian Unika Soegijapranata.

Rensiansi, Lutfi and Sri Iwaningsih. 2015. "Pengaruh Konsumsi Nasi IR-36 Dan Nasi Merah Terhadap Profil Kadar Gula Darah Pasien Diabetes Tipe 2 Di Puskesmas Kecamatan Pasar Rebo Jakarta Timur." ARGIPA (Arsip Gizi dan Pangan) 1(1):41-50.

Shimabukuro, Michio, Moritake Higa, Rie Kinjo, Ken Yamakawa, Hideaki Tanaka, Chisayo Kozuka, Kouichi Yabiku, Shin-Ichiro Taira, Masataka Sata, and Hiroaki Masuzaki. 2014. "Effects of the Brown Rice Diet on Visceral Obesity and Endothelial Function: The BRAVO Study." The British Journal of Nutrition 111(2):310-20.

Vora, Jyoti D., Nonita Madhrani, and Ashwati Sarman. 2015. "Biochemical, Organoleptic and Antimicrobial Characterization of Brown Rice (Oryza Sativa)." IOSR Journal of Environmental Science, Toxicology and Food Technology 9(5):41-45.

Widiyanti, Emi and Malik Cahyadin. 2015. "Analisis Rantai Usaha Padi (Beras) Merah Di Kabupaten Boyolali." JIEP 15(2):105-17.

\section{UCAPAN TERIMA KASIH}

Ucapan terima kasih disampaikan kepada pihak institusi Sekolah Tinggi Filsafat Jaffray Makassar yang telah mendukung kegiatan kewirausahaan kampus dan mendukung tulisan ini untuk dipresentasikan pada Seminar Nasional. 
